\title{
Inverted Squamous Cell Papilloma
}

National Cancer Institute

\section{Source}

National Cancer Institute. Inverted Squamous Cell Papilloma. NCI Thesaurus. Code C65165.

A benign epithelial neoplasm characterized by an endophytic growth, papillary pattern, and proliferation of neoplastic squamous cells without morphologic evidence of malignancy. 